\title{
Epistemolojik İnançlar Ölçeği Türkçe Formunun Geçerlik ve Güvenirlik Çalışması
}

Serhat AYDIN, Yrd. Doç. Dr., Karamanoğlu Mehmetbey Üniversitesi, aydins@kmu.edu.tr

Gülenaz SELÇUK, Yrd. Doç. Dr., Celal Bayar Üniversitesi, Eğitim Fakültesi

Altan ÇAKMAK, Yrd. Doç. Dr., Celal Bayar Üniversitesi, Eğitim Fakültesi

Abdurrahman İĞAN, Doç. Dr., Düzce Üniversitesi, Eğitim Fakültesi

Öz: Bu makalede epistemolojik inançları ortaya koyan ve Schommer tarafından geliştirilen Ingilizce ölçeğin Deryakulu ve Büyüköztürk tarafından gerçekleştirilen Türkçe uyarlamasının, Fen Bilgisi, Sosyal Bilgiler, Türkçe ve Sınıf Öğretmenliği bölümlerinden 1242 öğretmen adayı üzerinde geçerlik ve güvenirliğinin test edilmesi süreci anlatılacaktır. Açımlayıcı faktör analizinde üç faktörlü yapının toplam varyansın \%45'ini açıkladığı ve Cartell, Velicer ve Horn testlerinin üç faktörlü yapıyı doğruladığı bulunmuştur. Doğrulayıcı faktör analizinde üç faktörlü yapıya uyum parametreleri iyi seviyede (RMSEA = $0.05, \mathrm{NFI}=0.95, \mathrm{NNFI}=0.96, \mathrm{GFI}=0.90, \mathrm{AGFI}=0.88, \mathrm{CFI}=0.96)$ bulunmuştur. Üç faktörlü yapıda alt boyutlar için alfa iç tutarlılık güvenirlik katsayıları çaba alt boyutu için 0.88 , yetenek alt boyutu için 0.88 ve tek bir doğru alt boyutu için 0.85 olarak bulunmuştur. Tüm analizler sonucunda ölçeğin üç boyutlu yapıda geçerli ve güvenilir olduğu gösterilmiş ve zayıf bulunan maddeler için önerilerde bulunulmuştur. tepki kuramı

Anahtar Kelimeler: epistemolojik inançlar ölçeği, öğretmen adayları, geçerlik, güvenirlik, madde

\section{Validity and Reliability Study of Turkish Form of Epistemological Beliefs Scale}

\begin{abstract}
In this study the validity and reliability study of epistemological beliefs scale developed by Schommer and adapted by Deryakulu and Büyüköztürk on 1242 Class, Turkish, Science and Social Sciences preservice teachers was explained. In exploratory faktor analysis, it was found that three factor structure explained $45 \%$ of total variance and Cartell, Velicer and Horn tests confirmed three factor structure. In confirmatory factor analysis the goodness-of-fit statistics to three factor structure were found good (RMSEA $=0.05, \mathrm{NFI}=0.95, \mathrm{NNFI}=0.96, \mathrm{GFI}=0.90, \mathrm{AGFI}=0.88, \mathrm{CFI}=0.96)$. The alfa internal consistency coefficients were found as 0.88 for effort, 0.88 for ability and 0.85 for single truth subdimensions. As a result of all analyses, the scale was found valid and reliable with three factor structure and some recommendations were made for weak items.
\end{abstract}

Key Words: epistemological beliefs scale, preservice teachers, validity, reliability, item response theory 


\section{GíRiş}

İnançlar, bireyin düşünce ve davranışlarının önemli bir tanımlayıcısı ve yordayıcısı olması dolayısıyla bilimsel araştırmalarda önem arzetmektedir. Hofer (2001) kişisel epistemolojiyi, öğrencinin bilgi veya bilginin tanımlanması, bilginin nasıl inşa edildiği, bilginin nasıl değerlendirildiği, bilginin nereye dayandığı ve bilginin nasıl vuku bulduğu şeklinde bilmeyi içerdiğini ifade etmiştir. Bilginin doğası ve epistemolojik inançlara ilişkin inançlar uzun yıllardır eğitim araştırmalarında yer bulmuştur. Epistemolojik inançlar, bilginin kaynağı, gerekçelendirilmesi, yöntemi, doğası ve bilginin sınırları ve bilgi elde etmenin karakteristik özelliklerine ilişkin inançları betimlemektedir (Hofer, 2002; Schommer-Aikins, 2002). Eskiçağ felsefecilerinden günümüze kadar birçok araştırmacı ve düşünür, epistemolojik inançlara ilişkin; 'bilgi nedir?', 'bilgi nasıl elde edilir?', 'bilginin kaynağı nedir?', 'bilginin yapısı nedir?', 'bilginin sınırları nedir?', 'bilginin değeri nedir?', 'birşeyi bilmek ne demektir?' vb. şu soruların cevabını aramışlardır. Epistemolojik inançlar konunda ilk çalışmayı yapan Perry (1981; akt. Beownlee, Purdie ve Bolutan-Lewis, 2001) epistemolojik inançları bilginin ne olduğu, nasıl elde edildiği, mutlaklığı, sınırları ve ölçütüne ilişkin bireysel bakış açısının yansıması şeklinde tanımlarken; Schommer (1994) de Perry gibi benzer şekilde epistemolojik inançları; bilginin elde edilme hızı, bilginin belirsizliği, bilginin yapısı, bilginin kaynağı ve bilginin elde edilmesi üzerindeki kontrol şeklinde kısmen birbirinden bağımsız beş farklı inanç boyutundan oluşan bir yapı şeklinde tanımlamıştır. Güncel bir başka araştırmada ise (Kampa, Neumann, Heitmann ve Kremer, 2016) epistemolojik inançlar bilginin doğası alanı başlığında (a, mutlaklığı, b, bilimsel bilginin gelişimi) iki; bilmenin doğası alanında da (c, kaynağı, ve d, bilimsel bilginin gerekçelendirilmesi) iki boyut olmak üzere toplam dört boyuttan oluşan bir yapı kullanılmıştır. Örneğin Perry (1968; akt. Schommer-Aikins, Unruh ve Morphew, 2015) epistemolojik inançlar konusunda yapılan ilk çalışmada, Harvard Üniversitesi'nden lisans öğrenciler ile görüşmeler yapmıştır. Bu kapsamda lisans birinci sınıf öğrencilerinin bilginin basit, mutlak ve otorite tarafından aşağıya aktarıldığına inanma eğilimine sahip iken, son sınıf öğrencilerinin ise bilginin iç içe girmiş, kısmen belirsiz, sebep ve ampirik kanıtlar gibi çoklu kaynaklardan elde edildiği inancına yakın olduklarını ortaya koymuştur.

Parry (1970) ve ardından onu takip eden araştırmacılar (ör.; Baxter-Magolda, 1992, King ve Kitchener, 1994) epistemolojik inançların tek boyutlu olduğunu, basitten karmaşık düşünme süreci şeklinde boylamsal / uzun sürede geliştiğini varysaymışlardır. Perry'i takip eden diğer araştırmacılar (Schommer, 1990 gibi) genel epistemolojik inançlara akademik bir çalışma alanı perspektifinde yaklaşmışlardır. Buna rağmen, Perry'nin gelişimsel ve tek boyutlu modelini, bağımsız inançların daha az veya çok kavramsallaştırıldığı bir sisteme evrilmesi noktasına taşımışlardır. Epistemolojik inançların karmaşık olması dolayısıyla, tek bir boyutla ilişkili varsayımla betimlenmesinin uygun olmayacağı şeklinde kuramlaştırılmıştır. Bunun sonucunda öncelikle, bilginin (mutlaklığı, yapısı ve kaynağı) ve öğrenmenin (hızı ve kanıtlanabilirliği) şeklinde beş boyuttan oluşan hipotez kurulmuştur. Kuramlaştırılma bu inançların, eşzamanlı olarak gelişmek zorunda olmadığı şeklinde ortaya konulmuştur. Bu inançların eş zamansız olarak gelişmesi potansiyeli, sistemdeki her bir inancın çalışılmasını daha önemli hale getirmiştir (akt. Schommer-Aikins, Unruh ve Morphew, 2015).

Epistemolojik inançlara ilişkin boyutlardan, "bilginin mutlakiyeti", bilimsel bilginin doğru veya yanlış olarak görülmesinden, birden çok farklı perspektifte yansıması arasında uzanır. "Bilginin gelişimine" ilişkin inanç, bilimsel bilginin statik ve değişmez bir obje olmasından, bilimsel düşünce ve kuramların zaman içerisinde yeni kanıtlar ışı̆̆ında değişmesinin kabul edilmesi arasında uzanır. "Bilginin kaynağı", boyutu, bilginin bilim insanları ve öğretmenler gibi dış otoritelerden kaynaklanması şeklinde görülmesine karşı öğrenciler tarafından oluşturulması arasında görülmesini ifade etmektedir. "Bilginin gerekçelendirilmesi" 
ise fenomenlerin, deney veya gözlem gibi bilimsel incelemeler yoluyla keşfedilmesine karşı, bilginin akıl yürütme, düşünme ve çoklu deneyler ve gözlemler sonucunda ortaya çıkmasının anlaşılması arasında görülmesini ifade etmektedir (Conley, Pintrich, Vekiri, Harrison, 2004).

Epistemolojik inançların eğitim araştırmalarında kullanılmasının gerekçelerinin / öneminin başında, ilgili kavramın öğrencilerin bilgiyi işleme sürecini ve anlamlandırmalarına ilişkin gözetimini etkilemesinin yanında (Schommer, 1990), öğrenci öğrenmesinin önemli bir yordayıcISI olması (Chan, 2004; Hofer ve Pintrich, 1997; Kizilgunes, Tekkaya ve Sungur, 2009; Trautwein ve Lüdtke, 2007; Tsai, Jessie Ho, Liang ve Lin, 2011); öğrencinin öğrenme motivasyonuyla (Buehl ve Alexander, 2005; Mason, Boscolo, Tornatora ve Ronconi, 2013), öğrencinin kavramsal anlayışıyla (Songer, linn, 1991) ilişkisinin olması ve öğrenme ortamı ile bu ortamın kalitesi üzerinde etkili olmasıdır (Erdem, 2008). Hashweh (1996) sofistike epistemolojik inançlara sahip öğretmenlerin, öğrencinin alternatif kavramları konusundaki farkındalığının daha yüksek olduğunu, daha etkili öğretim stratejileri kullandıklarını ve öğrencilerinin öğrenmesini zenginleştirmek için daha nitelikli öğrenme çevresi oluşturduklarını ifade etmiştir. Bunun yanında, öğretmenlerin epistemolojik inançlarının, öğrenci çıktıları üzerindeki etkisine ilişkin yeterli miktarda alanyazın olmadığını söylemek mümkündür (Pamuk, Sungur ve Oztekin, 2016).

Türkiye'de yapılan bir araştırmada (Pamuk, Sungur ve Oztekin, 2016) epistemolojik inançların boyutlarının gelişimine ilişkin fen bilgisi öğretmenlerinin inançlarının, öğrencilerinin fen bilgisi dersindeki akademik başarısıyla pozitif yönde ilişkisi olduğu, ilaveten eğer öğretmen bilginin evrimleştiğine ve değiştiğine ilişkin güçlü bir inanca sahipse, öğrencilerinin fen bilgisi dersinde daha başarılı olma eğiliminde olduğu; bilginin doğrulanmasına ilişkin bilginin muhakeme, düşünme ve deneysel kaynaklı olduğu şeklinde sofistike epistemolojik inançların, öğrencileri daha anlamlı öğrenci olma ve dolayısıyla daha yüksek fen başarısı için teşvik ettiğini ortaya koymuştur.

$\mathrm{Bu}$ araştırmanın da öğretmen adayları üzerinden yapılmasından hareketle, öğretmen adaylarının epistemolojik inançlarının konu edinildiği benzer araştırmalar; epistemolojik inançların çok kültürlü eğitime yönelik tutumları ile epistemolojik inançları arasındaki ilişki (Türkan, Aydın, Üner, 2016), Hofer, Hammer ve Elby bağlamında sınıf öğretmeni adaylarının epistemolojik inançları (Cam, Sulun, Topcu, Guven, 2014), bilgi ve iletişim teknolojileri temelli karma öğretmenliğin epistemolojik inançlara etkisi (Erdem, 2008), sınıf öğretmeni adaylarının epistemolojik inançlarının sınıf ve cinsiyetlerine göre farklılaşma düzeyi (Şenler ve İrven, 2016), beden eğitimi öğretmenlerinin başarı hedefler ile epistemolojik inançları arasındaki ilişki (Canpolat, 2016), fen bilgisi öğretmen adaylarının bilim temelli epistemolojik inançlarına yönelik ölçek geliştirme çalışması (Koksal, Ertekin, 2016), epistemolojik inançların fen öğretimine uyumunu yordaması (Şahin, Deniz ve Topçu, 2016), epistemolojik inançlar ile akademik başarı arasındaki ilişki (Arslantaş, 2016), fen öğretmenlerinin epistemolojik inançları ile yapılandırmacı öğrenme çevresine ilişkin algıları arasındaki ilişki (Saylan, Armağan, Bektaş, 2016), öğretmen adaylarının epistemolojik inançları ile benimsedikleri eğitim felsefeleri arasındaki ilişki (Biçer, Er, Özel, 2013) öğretmen adaylarının epistemolojik inançlarının betimlenmesi (Erdamar, Alpan, 2011; İçen, İlğan, Göker, 2013; Kazu, Erten, 2015) şeklinde ortaya çıkmıştır. Adı geçen araştırmalardan görüleceği üzere öğretmen adaylarının epistemolojik inançlarının betimlenmesinin yanında birçok değişken ile ilişkisinin incelendiği anlaşılmaktadır.

Epistemolojik inançların ölçülmesi konusunda ilk çalışmaları yapanlardan olan Schommer'in (1990) geliştirdiği kişisel epistemolojik inançların; bilginin yapısı, kesinliği, kaynağı, kontrolü ve hızı adındaki beş alt boyutun / hipotezin test edildiği taslak ölçme aracı 63 maddeden oluşmuştur. Ölçme aracı 263 birinci ve son sınıf üniversite öğrencisine 
uygulanmıştır. Yapılan açımlayııı faktör analizi ölçme aracının a) bilgi basittir, b) bilgi mutlaktır, c) öğrenme yeteneği doğuştandır ve d) öğrenme hemen gerçekleşir boyutlarından oluştuğu ortaya çıkmakla birlikte güvenirliğe ilişkin bilgi raporlanmamıştır. Ardından 412 psikoloji bölümü öğrencisi üzerinde yapılan tekrar araştırmasında (Schommer, Crouse, Rhodes, 1992) yapılan açımlayıcı faktör analizinde ölçme aracı varyansın \%46'sını açıklamakla birlikte, önceki araştırmada ortaya çıkan dört boyutlu faktör yapısından farklı olarak; 'öğrenme yeteneğinin doğuştan geldiği' ve 'öğrenme hemen gerçekleşir' boyutlarının tek yapı altında birleşmek suretiyle üç faktörlü bir yapı ortaya çıkmıştır.

Bu araştırmada kullanılan Schommer (1993) in orijinal ölçeği, 63 madde ve 4 boyuttan oluşmakta iken; Türkiye'de ilk defa yapılan uyarlamasında (Deryakulu ve Büyüköztürk, 2002) ise üç faktörlü bir yapı (öğrenmenin çabaya bağlı olduğuna inanç, öğrenmenin yeteneğe bağlı olduğuna inanç ve tek bir doğrunun var olduğuna inanç) ortaya çıkmakla birlikte; ölçek yapısının yeniden incelendiği araştırmada ise (Deryakulu ve Büyüköztürk, 2005) 34 maddeden oluşan ölçeğin yine 3 boyuttan oluştuğu açımlayıcı faktör analizinin ardından yapılan doğrulayıcı faktör analizi ile de ortaya çıkmıştır. Chan ve Elliot (2000; 2004; akt. Aypay, 2011) temelde Schommer'in (1990) orijinal ölçeğine dayanmakla birlikte, uzmanlar tarafından yapılan eleştirileri de dikkate alarak, Hong Kong'lu öğretmen adayları üzerinde uyguladıkları, 45 maddeden oluşan taslak ölçme aracı üzerinde yaptıkları analizlerde 30 madde ve 4 boyuttan oluşan bir yapı, ölçeğin Türkçe uyarlama araştırmasında (Aypay, 2011) da, yapılan açımlayıcı ve doğrulayıcı faktör analizleriyle, ortaya çıkmıştır. Türkiye'de öğretmen adayları üzerinde yapılan bir başka çalışmasında ise (Oksal, Şenşekerci ve Bilgin, 2006) 23 maddeden oluşan ölçeğin "bilgi kaynağı olarak bilime inanç", "rasyonel topluma inanç", "batıl ritüellere inanç", "doğaüstü güçlere inanç" olmak üzere 4 boyuttan oluştuğu ortaya çıkmıştır. Pomeroy'un (1993) 50 maddeden oluşan "bilimsel epistemolojik inançlar" ölçeğini Türkçeye uyarlayan bir araştırmada (Deryakulu ve Bıkmaz, 2003) tek boyutlu olarak ortaya çıkan yapının 30 maddeden oluştuğu ortaya çıkmıştır.

Fen Bilgisi, Sosyal Bilgiler, Türkçe ve Sınıf Öğretmenliği bölümlerinde okuyan öğretmen adaylarının epistemolojik inançlarını belirlemek ve bu inançları demografik özellikler ve bölümlere göre karşılaştırmanın önemine ilişkin tartışmalar yukarıda açıklanmıştır. Bu amaç için öncelikle Türkçe'ye uyarlanmış "Epistemolojik İnançlar" ölçeğinin geçerlik ve güvenirlik testlerinin bu bölümlerde okuyan öğretmen adayları için sağlam bir şekilde yapılması gerekmektedir. Bu araştırma kapsamında, epistemolojik inançları konu edinen ölçek geliştirme / uyarlama çalışmalarından farklı olarak; geniş ölçekli bir örneklem (çalışma grubuna) ulaşılış olması, mevcut istatistik tekniklere ilave olarak popüler bir istatistik teknik olan Madde Tepki Kuramı kapsamında da analizlerin yapılmış olması, ölçme aracını kullanmak isteyen araştırmacılar için alternatifler içeren geçerli ve güvenilir birden çok ölçek versiyonları önermesi bakımlarından özgünlük ifade ettiğini söylemek mümkündür. Bu araştırma kapsamında elde edilen veriler üzerinde yapılan analizler sonucunda ortaya çıkan geçerli ve güvenilir epistemolojik inaç ölçeğinin başka çalışmalarda da kullanılması, öğretmen ve eğitimcilerin bir araştırma ve eğitim aracı olarak bu ölçekten bireysel olarak yararlanması mümkün olacaktır. Tüm bu nedenlerle bu çalışmanın amacı Schommer (1990) tarafından geliştirilen Epistemolojik İnançlar Ölçeğinin, Deryakulu ve Büyüköztürk tarafından gerçekleştirilen Türkçe uyarlamasının, dört farklı bölümden öğretmen adayları üzerinde geçerlik ve güvenirliğinin test edilmesi olarak belirlenmiştir. 


\section{YÖNTEM}

\section{1. Çalışma Grubu}

Çalışma grubunu Ege Bölgesinde bir üniversitede, fen bilgisi, sosyal bilgiler, Türkçe ve sınıf öğretmenliği programlarında okuyan ve çalışmaya gönüllü katılan 1242 öğretmen adayı oluşturmuştur. Araştırmanın verileri 2015-2016 öğretim yılında toplanmıştır. Çalışmanın örnekleminde yer alan 1242 öğretmen adayının demografik özellikleri Tablo 1'de gösterilmektedir.

Tablo 1

Çalışma Grubu

\begin{tabular}{|c|c|c|c|}
\hline Değişken & Düzeyler & Frekans & Yüzde \\
\hline \multirow[t]{2}{*}{ Cinsiyet } & Kadın & 753 & $\% 60.6$ \\
\hline & Erkek & 489 & $\% 39.4$ \\
\hline \multirow[t]{4}{*}{ Sinıf } & 1 & 239 & $\% 19.2$ \\
\hline & 2 & 197 & $\% 15.9$ \\
\hline & 3 & 431 & $\% 34.7$ \\
\hline & 4 & 375 & $\% 30.2$ \\
\hline \multirow[t]{5}{*}{ Bölüm } & Türkçe Öğretmenliği & 206 & $\% 16.6$ \\
\hline & Fen Bilgisi Öğretmenliği & 323 & $\% 26.0$ \\
\hline & Sosyal Bilgiler Öğretmenliği & 311 & $\% 25.0$ \\
\hline & Sınıf Öğretmenliği & 402 & $\% 32.4$ \\
\hline & Toplam & 1242 & $\% 100$ \\
\hline
\end{tabular}

Tablo 1'e cinsiyet açısından bakıldığı zaman örneklemdeki 1242 öğretmen adayının 753'ü (\%60.6) kadın ve 489'u (\% 39.4) erkektir. Sınıf düzeyi açısından öğretmen adaylarının 239'u (\%19.2) 1. Sınıf, 197'si (\% 15.9) 2. Sınıf, 431'i (\% 34.7) 3. Sınıf ve 375'i (\% 30.2) 4. Sinıfta okumaktadır. Bölüm açısından ele alındığında, öğretmen adaylarının 206'sı (\%16.6) Türkçe Öğretmenliği, 323'ü (\% 26.0) Fen Bilgisi Öğretmenliği, 311'i (\% 25.0) Sosyal Bilgiler Öğretmenliği ve 402 'si (\% 32.4) Sınıf Öğretmenliği Programında okumaktadır. Demografik değişkenlerle ilgili Tablo 1'de yer alan verilere bakıldığında özetle kategorilere dengeli bir biçimde dağılım gösterdiği, evreni temsil etme niteliği taşıdığı ve geçerlik-güvenirlik analizleri için uygun olduğu yorumu yapılabilir.

\subsection{Veri Toplama Aracı}

Bu çalışmada kullanılan epistemolojik inançlar ölçeği İngilizce olarak Schommer (1990) tarafından geliştirilmiştir. Ölçeğin İngilizce'den Türkçe'ye uyarlanması Deryakulu ve Büyüköztürk (2005) tarafından yapılmıştır. Orijinal ölçek 1. Doğuştan gelen yetenek, 2. Hızlı öğrenme, 3. Kesin bilgi ve 4. Basit bilgi şeklinde 4 faktörlü yapıda bulunmuştur. Ölçeğin Deryakulu ve Büyüköztürk tarafından gerçekleştirilen uyarlaması ise 1. Başarının çabaya bağlı olduğu, 2. Başarının yeteneğe bağlı olduğu ve 3. Tek bir doğrunun varlığına inanç şeklinde üç faktörlü yapıda bulunmuştur. Epistemolojik inanç ölçeğinin Türkçe'ye uyarlanmasının üzerinden makul bir süre geçmesinin yanında, bu araştırma kapsamında ileri istatistik tekniklerle ölçek test edilmiştir.

\subsection{Veri Analizi ve İşlem}

Öncelikle ölçek sahibinden ve Türkçe uyarlamayı yapan yazarlardan gerekli izinler alınmıştır. Bundan sonra ölçeğin Türkçe formu çalışma grubuna uygulanmıs ve elde edilen veri setine geçerlik ve güvenirlik analizleri uygulanmıştır. Geçerlik analizleri olarak açımlayıcı ve doğrulayıcı faktör analizleri yapılmıştır. Faktör analizlerinde öncelikle veri setinin faktör analizlerine 
uygunluğuna bakılmıştır. Faktör analizine uygunluk; normallik, uç ve kayıp değerler ve örneklem büyüklüğü testleri ve Bartlett küresellik testleri ile belirlenmiştir. Daha sonra SPSS programında açımlayıcı faktör analizi yapılarak açıklanan toplam varyans, faktör yükleri ve Kaiser, Cartell, Velicer ve Horn testleriyle tutulacak faktör sayısı belirlenmiştir. Daha sonra Lisrel programıyla doğrulayıcı faktör analizi yapılmış ve eldeki veri setinin modele uyum parametreleri incelenmiştir.

Güvenirlik analizleri olarak madde-toplam korelasyonları, iç tutarlılık alfa, omega ve GLB katsayıları hesaplanmıştır. Bunlara ilaveten güvenirlik kanıtları olarak IRTPro programında örtük özellik analizleri (Madde Tepki Kuramı analizleri) yapılmış ve ölçeğin gösterdiği yapıdaki alt boyutlar için tutarlılık ve her bir madde için ayırt edicilik değerleri hesaplanmıştır. Son olarak tüm analizler birleştirilerek geçerlik ve güvenirlik sonuçları yorumlanmıştır.

\section{BULGULAR}

Bu bölümde çalışmanın bulguları açıklanarak yorumlanmıştır. Bulgular sırasıyla geçerlik ve güvenirlik çalışmaları şeklinde ele alınmıştır.

\subsection{Geçerlik Çalışmaları}

Öncelikle uygulamadan elde edilen veri setinin faktör analizlerine uygunluğu incelenmiştir. Bu amaçla veri seti için normallik, kayıp değerler, uç değerler, çoklu doğrusallık ve tekillik testleri, örneklem büyüklüğü testleri, Bartlett küresellik testi ve korelasyon testleri (madde-madde ve anti-image) yapılmıştır. Analizler sonucunda ölçekteki tüm maddelerin normallik varsayımlarını sağladığı (Rosnow ve Rosenthal, 2008) hiç bir madde için kayıp değerler bulunmadığı görülmüştür. Diğer yandan uygulamadan elde edilen veri setinde 30 uç değer (\% 2.4) tespit edilmiştir. Bu uç değerlerin veri setinden çıkartılmasına karar verilmiştir. Uygulamadan elde edilen veri seti için yapılan analizlerde $(r \geq .90)$ çoklu doğrusallık ve tekillik $(r=1)$ sorunlarına rastlanmamıştır (Şekercioğlu, 2009). Örneklem büyüklüğü ( $n=1242)$ faktör analizleri için mükemmel (Comrey ve Lee, 1992), katılımcı sayısı - madde oranı (1242 / 35) çok iyi düzeyde (Bryman ve Cramer, 2001) ve KMO değeri (=.93) mükemmel seviyede (Şencan, $2005)$ bulunmuştur. Bartlett küresellik testi sonuçlarına göre $(p<.05)$ veri seti çok değişkenli normallik varsayımlarını sağlamıştır (Şencan, 2005). Daha sonra madde-madde ve anti-image korelasyon matrislerine bakılmış ve aynı faktörler altında bulunan maddeler arasındaki korelasyonların istatistiksel açıdan anlamlı (Günüç ve Kayri, 2010) ve anti-image korelasyon matrislerinin sorunsuz olduğu görülmüştür (Altunışık, Coşkun, Bayraktaroğlu ve Yıldııı, 2005). Bu sonuçlara göre eldeki veri setine faktör analizleri uygulanabileceği yorumu yapılmıştır.

Bu aşamada eldeki veri setine öncelikle Açımlayıcı Faktör Analizi (AFA) yapıımıştır. AFA'da faktörleşme tekniği olarak temel bileşenler analizi, döndürme tekniği olarak Kaiser normalizasyonu ile Varimax yöntemi kullanılmıştır. AFA'da tutulacak faktör sayısını belirlemek için farklı kriterler kullanılmıştır. Bunlardan ilki olan açıklanan toplam varyans miktarı kriterine göre ölçek üç faktörlü yapıyla toplam varyansın \%45'ini açıklamıştır. Büyüköztürk (2009), sosyal bilimlerde toplam varyansın \%40'ı bile açıklansa yeterli kabul edilebileceğini bildirmiştir. Üç faktörlü yapıda faktör yük değerlerinin tüm maddeler için yeterli bulunan 0.4 üzerinde olduğu (Beavers vd., 2013) fakat bazı maddelerde binişik yük değerleri bulunduğu görülmüştür. Buna karşın üç faktörlü modelde ortak faktör varyanslarının bazı maddeler için 0.4 ve bazı maddeler için de 0.3 altında kaldığı görülmüştür. Tutulacak faktör sayısını belirlemek için daha sonra literatürde önerildiği gibi

i.) K1- Kaiser'in birden büyük özdeğer (eigenvalue) kuralı

ii.) Cartell'in scree plot (yamaç birikinti grafiği) yöntemi

iii.) Velicer'in MAP(Minimum Average Partial) testi ve 
iv.) Horn'un paralel analizi

birlikte kullanılmıştır (Ledesma ve Valero-Mora, 2007). Bu testlerin ilk ikisi SPSS'te standart olarak sunulmakta ve son ikisi için ilave komut satırları kullanılmaktadır. Bu testlerden ilki tutulacak faktör sayısını altı olarak bulurken diğer üç test üç olarak bulmuştur. AFA sonuçları Tablo 2'de ayrıntılı olarak gösterilmektedir.

Tablo 2

Açımlayıcı Faktör Analizi Sonuçları

\begin{tabular}{|c|c|c|c|c|c|c|}
\hline KMO & \multicolumn{6}{|c|}{.933} \\
\hline BARTLETT & \multicolumn{6}{|c|}{.000} \\
\hline & \multicolumn{6}{|c|}{ Tutulacak Faktör Sayısı } \\
\hline Kaiser's & \multicolumn{6}{|c|}{6} \\
\hline Cartell's & \multicolumn{6}{|c|}{3} \\
\hline Velicer's & \multicolumn{6}{|c|}{3} \\
\hline Horn's & \multicolumn{6}{|c|}{3} \\
\hline \multicolumn{7}{|c|}{ Faktörler Tarafından Açıklanan Toplam Varyans \% } \\
\hline 1. Faktör & \multicolumn{6}{|c|}{22} \\
\hline 2. Faktör & \multicolumn{6}{|c|}{36} \\
\hline 3. Faktör & \multicolumn{6}{|c|}{45} \\
\hline & \multicolumn{3}{|c|}{ Faktör Yükleri } & \multicolumn{3}{|c|}{ Orta Faktör Varyansları } \\
\hline MADDE & Faktör 1 & Faktör 2 & Faktör 3 & Faktör 1 & Faktör 2 & Faktör 3 \\
\hline C1* & .592 & & & 0.364 & & \\
\hline $\mathrm{C} 2 *$ & .592 & & & 0.368 & & \\
\hline C3 & .646 & & & 0.449 & & \\
\hline $\mathrm{C} 4^{* *}$ & .519 & & & 0.277 & & \\
\hline C5 & .630 & & & 0.417 & & \\
\hline $\mathrm{C} 6 * *$ & .444 & & & 0.207 & & \\
\hline $\mathrm{C} 7^{* *}$ & .472 & & & 0.226 & & \\
\hline $\mathrm{C} 8 * *$ & .537 & & & 0.293 & & \\
\hline C9 & .618 & & & 0.415 & & \\
\hline C10 & .640 & & & 0.445 & & \\
\hline C11 & .630 & & & 0.455 & & \\
\hline C12* & .546 & & & 0.310 & & \\
\hline C13 & .626 & & & 0.411 & & \\
\hline C14 & .642 & & & 0.422 & & \\
\hline C15 & .643 & & & 0.417 & & \\
\hline C16* & .582 & & & 0.340 & & \\
\hline C17* & .529 & & & 0.328 & & \\
\hline Y1 & & .672 & & & 0.483 & \\
\hline Y2 & & .707 & & & 0.507 & \\
\hline Y3 & & .744 & & & 0.570 & \\
\hline Y4 & & .664 & & & 0.447 & \\
\hline Y5 & & .787 & & & 0.654 & \\
\hline Y6 & & .719 & & & 0.536 & \\
\hline$Y 7^{* *}$ & & .537 & & & 0.298 & \\
\hline Y8 & & .676 & & & 0.490 & \\
\hline Y9 & & .648 & & & 0.492 & \\
\hline T1D1 $^{Y}$ & & .575 & & & & 0.474 \\
\hline T1D2* & & & .434 & & & 0.305 \\
\hline T1D3 $*^{\mathrm{B}}$ & & .436 & .444 & & & 0.387 \\
\hline $\mathrm{T}^{\mathrm{DD}} 4^{\mathrm{B}}$ & & .467 & .456 & & & 0.466 \\
\hline T1D5* & & & .542 & & & 0.341 \\
\hline T1D6* & & & .552 & & & 0.319 \\
\hline T1D7 & & .414 & .503 & & & 0.434 \\
\hline
\end{tabular}




\begin{tabular}{cl|l} 
T1D8 & .574 & 0.423 \\
T1D9 & .648 & 0.484 \\
\hline & ${ }^{Y}$ AFA sonuçlarına göre yanlış faktörle ilişkili \\
* AFA sonuçlarına göre zayıf madde & bulunan madde \\
** AFA sonuçlarına göre çok zayıf madde & ${ }^{B}$ AFA sonuçlarına göre binişik (birden fazla \\
& faktörle ilişkili bulunan) madde \\
\hline
\end{tabular}

Tablo 2'de gösterilen AFA sonuçlarına göre ölçek üç faktörlü yapıyla toplam varyansın \%45'lik bir bölümünü açıklamıştır ve bu miktar sosyal bilimlerde bir ölçek için yeterli bulunmaktadır (Büyüköztürk, 2009). Üç faktörlü yapıda faktör yük değerlerinin tüm maddeler için yeterli bulunan 0.4 üzerinde olduğu (Beavers vd., 2013) fakat bazı maddelerde binişik yük değerleri bulunduğu görülmüştür. Buna karşın üç faktörlü modelde ortak faktör varyanslarının bazı maddeler için 0.4 ve bazı maddeler için de 0.3 altında kaldığı görülmüştür. Tutulacak faktör sayısını belirlemek için daha sonra literatürde önerildiği gibi i.) K1- Kaiser'in birden büyük özdeğer (eigenvalue) kuralı, ii.) Cartell'in scree plot (yamaç birikinti grafiği) yöntemi, iii.) Velicer'in MAP(Minimum Average Partial) testi ve iv.) Horn'un paralel analizi birlikte kullanılmıştır (Ledesma ve Valero-Mora, 2007). Bu testlerden ilki tutulacak faktör sayısını altı olarak bulurken diğer üç test üç olarak bulmuştur. Tüm bu bulgularla AFA sonucunda ölçeğin üç faktörlü yapıda olduğu yorumu yapılmıştır.

Bundan sonra eldeki veri setine Doğrulayıcı Faktör Analizi (DFA) uygulanmıştır. Bu şekilde eldeki veri setine göre ölçeğin Türkçe formunun yapı geçerliği yani literatürde bildirilen yapıya uygunluğu araştırılmıştır (Santor vd., 2011). DFA sonuçları Şekil 1'de gösterilmektedir. 


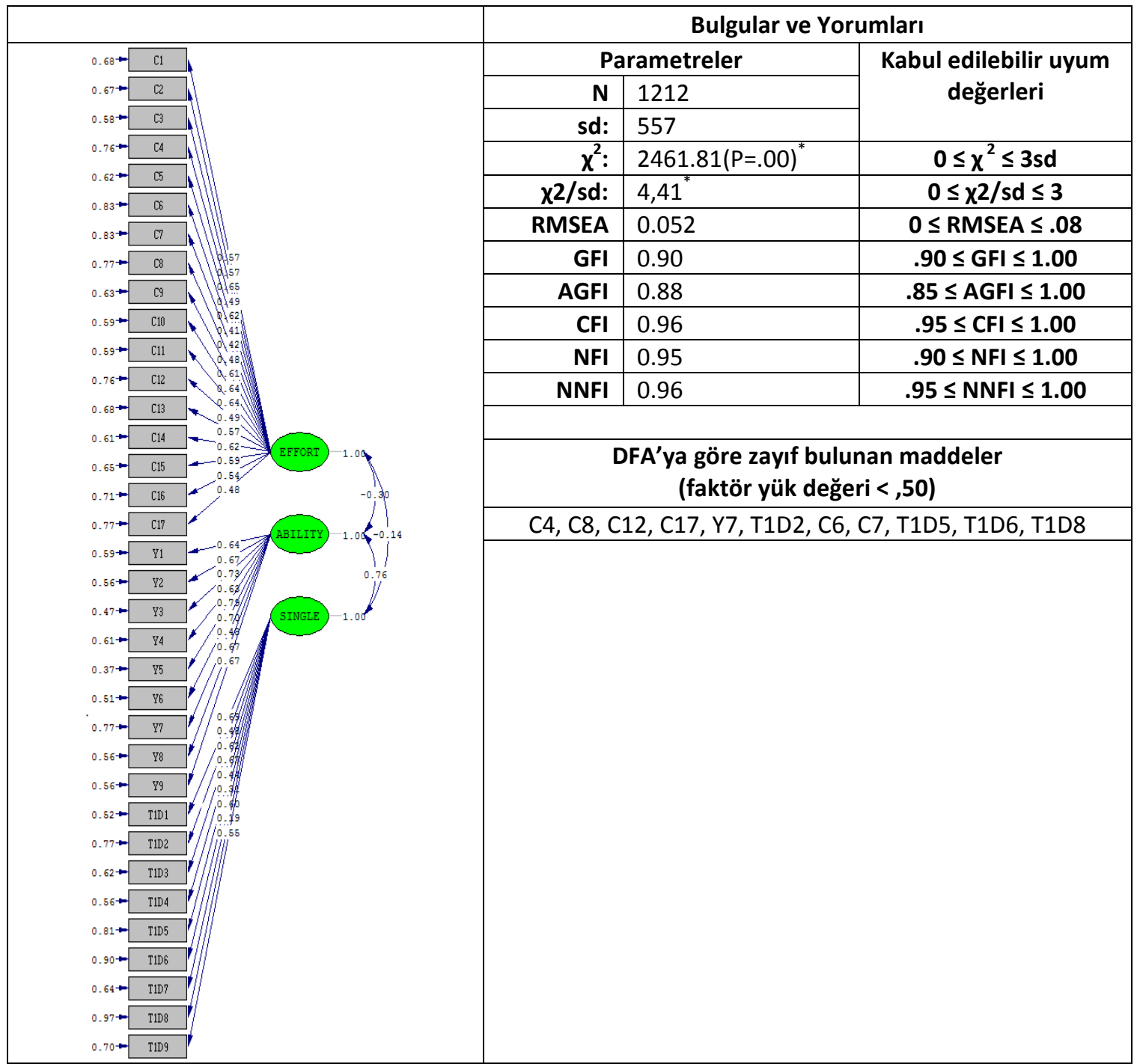

Şekil 1. Doğrulayıcı Faktör Analizi Sonuçları

Şekil 1 de gösterilen DFA'da elde edilen uyum indeksi değerleri incelenmiş ve Ki-kare değerinin $(\chi 2=2461.81, N=1212, p=0.00, \chi 2 / s d=4.41)$ anlamlı olduğu görülmüştür. Diğer uyum indeksi değerleri ise RMSEA $=0.05, \mathrm{NFI}=0.95$ ve NNFI $=0.96, \mathrm{GFI}=0.90, \mathrm{AGFI}=0.88, \mathrm{CFI}=$ 0.96 olarak elde edilmiştir. $\chi 2$ ve $\chi 2 /$ sd değerleri sınırda olmakla birlikte diğer tüm uyum değerlerinin kabul edilebilir düzeyde olduğu ve ölçeğin üç faktörlü modele iyi uyum sağladığı söylenebilir (Bryne, 2001). DFA'da ayrıca C4, C8, C12, C17, Y7, T1D2, C6, C7, T1D5, T1D6, T1D8 maddelerinin diğerlerinden daha zayıf olduğu görülmüştür.

DFA sonuçlarına göre ölçek 35 maddelik orijinal haliyle kullanılabilir. Ancak yine de AFA, güvenirlik analizleri ve uzman görüşlerine göre zayıf olan maddelerde düzeltme yapılması veya zayıf maddelerin çıkarılması düşünülebilir.

\subsection{Güvenirlik çalışmaları}

$\mathrm{Bu}$ bölümde ölçeğin Türkçe formu için güvenirlik analizlerinin bulguları açıklanmaktadır. Güvenirlik kanıtları olarak öncelikle ölçeğin üç farklı faktörüne ait maddetoplam korelasyonlarına bakılmıştır. Sonuçlar Tablo 3'te gösterilmektedir. 
Tablo 3

Madde-Toplam Korelasyonları

\begin{tabular}{ccccccc|} 
& $\begin{array}{c}\text { Faktör 1 } \\
\text { Çaba }\end{array}$ & \multicolumn{2}{c}{$\begin{array}{c}\text { Faktör 2 } \\
\text { Yetenek }\end{array}$} & \multicolumn{2}{c}{$\begin{array}{c}\text { Faktör 3 } \\
\text { Tek Bir Doğru }\end{array}$} \\
\hline MADDE & r & MADDE & r & MADDE & r \\
\hline C1 & .638 & Y1 & .684 & T1D1 & .657 \\
C2 & .487 & Y2 & .723 & T1D2 & .573 \\
C3 & .503 & Y3 & .769 & T1D3 & .645 \\
C4 & .546 & Y4 & .694 & T1D4 & .668 \\
C5 & .625 & Y5 & .801 & T1D5 & .567 \\
C6 & .647 & Y6 & .737 & T1D6 & .501 \\
C7 & .643 & Y7 & .561 & T1D7 & .649 \\
C8 & .545 & Y8 & .708 & T1D8 & .394 \\
C9 & .604 & Y9 & .698 & T1D9 & .658 \\
C10 & .635 & & & & \\
C11 & .626 & .576 & & & & \\
C12 & .575 & & & \\
C13 & .525 & & & & \\
C14 & .638 & .487 & & & & \\
C15 & .503 & & & & \\
C16 & .546 & & & & & \\
C17 & & & & & & \\
\hline
\end{tabular}

Madde-toplam korelasyonları 0.394 - 0.801 aralığında değerler almıştır. Madde-toplam korelasyonları için 0.30 üzerindeki değerlerin yeterli olduğu yorumu yapılımaktadır (Derebaşı, 2004).

Daha sonra ölçek için iç tutarlılık güvenirlik katsayıları hesaplanmıştır. Bu amaçla Cronbach alpha, Mc Donald omega ve GLB katsayısılarının beraber değerlendirilmesi önerilmektedir (Peters, 2014). Ayrıca iç tutarlılık için tek bir değer belirlemek yerine güven aralığı bulmanın daha uygun olacağını savunan araştırmacılar vardır (Dunn vd., 2013; Peters, 2014). Bu çalışmada R (R Development Core Team, 2014) yazılımı yardımıyla alfa, omega ve GLB değerleri ve güven aralıkları hesaplanmıştır. Sonuçlar Tablo 4'te verilmektedir. 


\begin{tabular}{|c|c|c|c|c|c|c|c|c|c|c|c|c|c|}
\hline & \multicolumn{5}{|c|}{ Nokta kestirimleri } & \multicolumn{2}{|c|}{ Güven aralıkları } & \multicolumn{4}{|c|}{ Nokta kestirimleri } & \multicolumn{2}{|c|}{ Güven aralıkları } \\
\hline & $\begin{array}{l}\overline{\overline{\widetilde{J}}} \\
\stackrel{ \pm}{ \pm} \\
\mathbb{8} \\
\stackrel{0}{0} \\
\tilde{0}\end{array}$ & 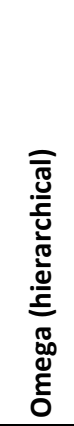 & 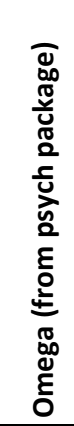 & 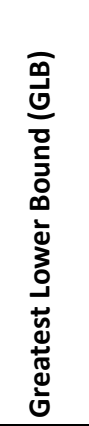 & 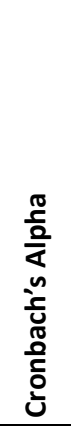 & $\begin{array}{l}\text { Omega } \\
\text { (total) }\end{array}$ & Alpha & 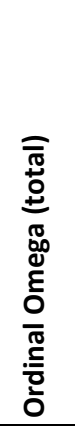 & 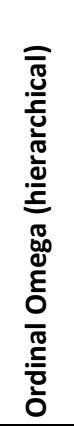 & 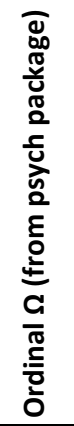 & 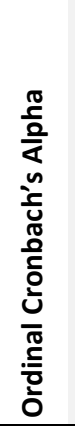 & $\begin{array}{l}\text { Ordinal } \\
\text { Omega } \\
\text { (total) }\end{array}$ & $\begin{array}{l}\text { Ordinal } \\
\text { Alpha }\end{array}$ \\
\hline & $\Omega$ & $\Omega$ & $\Omega$ & GLB & $\alpha$ & $\Omega$ & $\alpha$ & $\Omega$ & $\Omega$ & $\Omega$ & $\alpha$ & $\Omega$ & $\alpha$ \\
\hline C & .88 & .69 & .89 & .91 & .88 & {$[.87, .89]$} & {$[.87, .89]$} & .92 & .82 & .92 & .91 & {$[.90, .92]$} & {$[.90, .92]$} \\
\hline$Y$ & .88 & .75 & .89 & .89 & .88 & {$[.87, .89]$} & {$[.87, .89]$} & .92 & .78 & .92 & .91 & {$[.90, .92]$} & {$[.90, .91]$} \\
\hline T1D & .85 & .74 & .87 & .88 & .85 & {$[.84, .86]$} & {$[.84, .86]$} & .91 & .78 & .91 & .88 & {$[.88, .89]$} & {$[.88, .89]$} \\
\hline
\end{tabular}

C=Çaba faktörü

T1D=Tek bir došru faktöru

Tablo 4'te gösterilen iç tutarlılık hesaplamalarına göre hem nokta hem güven aralığı kestirimlerinin tamamında, ayrıca omega, alpha ve GLB değerlerinin tamamında ölçeğin Türkçe formu yüksek düzeyde güvenilir bulunmuştur. Ölçme araçları için 0.70 üzeri alfa değerinin kabul edilebilir düzey olduğu bildirilmektedir (Tezbaşaran, 1996). Bu kritere göre Epistemolojik Inançlar Ölçeği Türkçe Formu faktörleri için alfa katsayıları çaba alt boyutu için 0.88 , yetenek alt boyutu için 0.88 ve tek bir doğru alt boyutu için 0.85 olarak bulunmuştur. Bu değerlere göre ölçeğin her üç faktörü de kabul edilebilir düzeyde güvenilir bulunmuştur. Diğer yandan alfa iç tutarlılık değerlerini doğrulamak için Omega değerlerine bakıldığında sırasıyla $0.89,0.89$ ve 0.87 olarak alfa değerlerinden 0.02 puan yüksek bulunmuştur. Omega katsayısının alfa katsayısından daha güvenilir olduğu ve bu sonuçlara göre ölçeğin her üç alt boyutu için de güvenirliğin yüksek olduğu yorumu yapılabilir (Peters, 2014). GLB katsayıları ise sırasıyla 0.91, 0.89 ve 088 olarak bulunmuştur. Bu değerlere göre de ölçeğin her üç alt boyutu için güvenirliğin yüksek olduğu yorumu yapılabilir (Peters, 2014). İç tutarlılık için sıralama ölçeği varsayımına göre ise elde edilen değerlerin oran ölçeği varsayımına göre daha yüksek olduğu ve oran ölçeği varsayımından elde edilen sonuçları doğruladığı yorumu yapılabilir (Dunn vd., 2013).

Bundan sonra elde edilen güvenirlik sonuçlarını doğrulamak için Madde Tepki Kuramı (MTK) olarak ta adlandırılan örtük özellik analizleri (Hambleton ve Swaminathan, 1985; Lord, 1980) yapılmıştır. Bunun için IRTPro yazılımından yararlanılmıştır. Bu analizlerde önce iki parametreli lojistik model (2PL) kullanılarak ölçeğin Türkçe formunun üç faktörlü yapıya uyumuna bakılmıştır. Burada eldeki verinin modele uyumunu ortaya koyan parametre değerleri (örn. RMSEA $\leq$ 0.05) Klasik Test Kuramı'nda alfa iç tutarlılık katsayısına benzer bir sonuçtur (Gültaş, 2014; Aydın, 2014). Sonuçlar Tablo 5 'te gösterilmektedir. 
Tablo 5

MTK Model Uyum Parametreleri

\begin{tabular}{lccccc} 
& RMSEA & $\mathbf{M}_{\mathbf{2}}$ & sd & $\mathbf{M}_{\mathbf{2}} / \mathbf{s d}$ & $\boldsymbol{p}$ \\
\hline Çaba & 0.03 & 3929.80 & 2159 & 1.82 & .0001 \\
Yetenek & 0.05 & 1959.40 & 567 & 3.45 & .0001 \\
Tek1Doğru & 0.05 & 2715.11 & 567 & 4.79 & .0001 \\
\hline
\end{tabular}

Bu sonuçlara göre (RMSEA < 0.05 ) eldeki veri setinin ölçeğin Türkçe formu için üç faktörlü yapıyı doğruladığı söylenebilir. Buna göre ölçeğin her bir alt boyutu güvenilirdir. Bundan sonra üç faktörlü yapıda ölçeğin her bir faktörü için madde tepki kuramına göre test karakteristik, bilgi ve hata fonksiyonları ve ayrıca her bir madde için ayırt edicilik parametreleri hesaplanmıştır (Gültaş, 2014; Ledesma ve Valero-Mora, 2007). Sonuçlar Şekil 2'de gösterilmektedir.

Ayırt edicilik parametreleri 1 'in üzerinde olan maddeler yeterli kabul edilmektedir (Gültaş, 2014; Ledesma ve Valero-Mora, 2007; Aydın, 2014). Buna göre ayırt ediciliği yetersiz maddeler C6, C7, Y7, T1D2, T1D5, T1D6, T1D8'dir. Ayırt ediciliği sınırda olan maddeler ise C1, C2, C4, C8, C12'dir. Diğer maddelerin ayırt edicilikleri yeterli düzeydedir.

Her üç faktörde de test karakteristik eğrisinde örtük değişkende az bir değişme ile ani artış görülmekte yani testin tamamı için güçlü bir ayırt edicilik bulunmaktadır (Gültaş, 2014; Ledesma ve Valero-Mora, 2007; Aydın, 2014). Test bilgi ve hata fonksiyonlarına bakıldığında, "çaba" etiketli faktör örtük değişkenin alt ve orta düzeyleri için çok bilgi sunarken örtük değişkenin çok üst düzeyleri için yetersiz bilgi sunmaktadır. Diğer yandan, "yetenek" ve "tek1doğru" faktörleri örtük değişkenin alt düzeyi için yetersiz bilgi sunarken, orta ve üst düzeyleri için çok bilgi sunmaktadır. Hata fonksiyonları da aynı bilgiyi doğrular şekilde faktörlerin çok bilgi sunduğu düzeylerde az hata gösterirken örtük değişkenin çok bilgi sunduğu düzeylerde çok yüksek hata göstermektedir.

Özetle, epistemolojik inanç ölçeğinin "çaba" faktörü "başarının çabaya bağlı olduğuna" alt ve orta düzeyde inançlar için çok kullanışlı iken üst düzeyde inançlar için kullanışlı değildir. Tam aksine, ölçeğin "yetenek" ve "tek1doğru" faktörleri "başarının yeteneğe bağlı olduğu" ve "tek bir doğrunun varlığına" alt düzeyde inançlar için kullanışsız iken üst düzeyde inançlar için daha kullanışıdır. 


\begin{tabular}{|c|c|c|c|c|c|}
\hline \multicolumn{4}{|c|}{ Ayırtedicilik parametreleri } & \multirow{2}{*}{ Test Karakteristik Eğrisi } & \multirow{2}{*}{ Test Bilgi ve Hata Fonksiyonları } \\
\hline & Madde & $a$ & s.h. & & \\
\hline 1 & $C$ & 0.94 & 0.08 & & \\
\hline 2 & C & 1.07 & 0.08 & & \\
\hline 3 & C & 1.39 & 0.1 & & \\
\hline 4 & C & 0.98 & 0.08 & & \\
\hline 5 & C & 1.46 & 0.1 & & \\
\hline 6 & $\mathrm{C}$ & 0.82 & 0.07 & & \\
\hline 7 & C & 0.87 & 0.07 & & 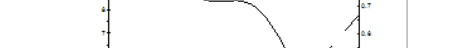 \\
\hline 8 & C & 1.01 & 0.08 & & 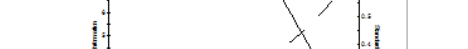 \\
\hline 9 & C & 1.46 & 0.1 & & \\
\hline 10 & C & 1.56 & 0.11 & & \\
\hline 11 & C & 1.58 & 0.11 & & \\
\hline 12 & C & 1.06 & 0.08 & (a) & 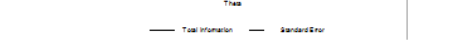 \\
\hline 13 & C & 1.27 & 0.09 & & \\
\hline 14 & C & 1.64 & 0.11 & & \\
\hline 15 & C & 1.41 & 0.10 & & \\
\hline 16 & C & 1.34 & 0.09 & & \\
\hline 17 & C & 1.18 & 0.09 & & \\
\hline 1 & $\mathrm{Y}$ & 1.27 & 0.10 & & \\
\hline 2 & $Y$ & 1.33 & 0.09 & & \\
\hline 3 & $Y$ & 1.67 & 0.11 & & \\
\hline 4 & $\mathrm{Y}$ & 1.22 & 0.09 & & 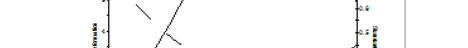 \\
\hline 5 & $\mathrm{Y}$ & 2.37 & 0.16 & & \\
\hline 6 & $\mathrm{Y}$ & 1.57 & 0.10 & & 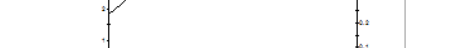 \\
\hline 7 & $Y$ & 0.69 & 0.07 & & \\
\hline 8 & $\mathrm{Y}$ & 1.29 & 0.09 & 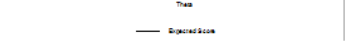 & 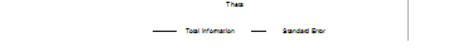 \\
\hline 9 & $\mathrm{Y}$ & 1.23 & 0.09 & & \\
\hline 1 & T1D & 1.13 & 0.11 & & \\
\hline 2 & T1D & 0.62 & 0.08 & & \\
\hline 3 & T1D & 1.21 & 0.10 & & \\
\hline 4 & T1D & 1.45 & 0.12 & & 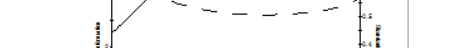 \\
\hline 5 & T1D & 0.76 & 0.08 & & 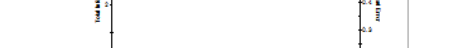 \\
\hline 6 & T1D & 0.63 & 0.08 & & 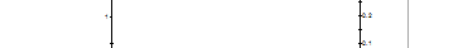 \\
\hline 7 & T1D & 1.19 & 0.10 & $\dot{n}$ & 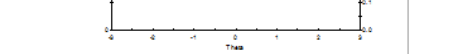 \\
\hline 8 & T1D & 0.41 & 0.08 & - & - \\
\hline
\end{tabular}

Şekil 2. Faktörlerin Test Karakteristik Eğrileri, Test Bilgi ve Hata Fonksiyonları, Madde Ayırt Edicilik Parametreleri

\section{SONUÇ, TARTIŞMA VE ÖNERILER}

Bu araştırmada Schommer (1993) tarafından geliştirilen ve Deryakulu ve Büyüköztürk tarafından (2002) Türkçe'ye uyarlaması yapılan 35 maddelik Epistemolojik İnançlar Ölçeği Türkçe Formu'nun güncel ve dört farklı bölümden 1242 öğretmen adayı üzerinde geçerlik ve güvenirlik analizleri anlatılmaktadır. Schommer (1993), orijinal ölçeği dört faktörlü bulmasına rağmen Deryakulu ve Büyüköztürk $(2002 ; 2005)$ ölçeği üç faktörlü yapıda bulmuşlardır. Deryakulu ve Büyüköztürk (2002; 2005)'ün bulgularını daha büyük ve çeşitlilik içeren bir örneklemde doğrulamak için bir ihtiyaç bulunduğu görülmüştür. Bu amaçla geçerlik ve güvenirlik analizleri yapılmıştır. 
Geçerlik analizleri olarak AFA ve DFA yapılmıştır. Güvenirlik analizleri olarak maddetoplam korelasyonları ile iç tutarlıık alfa, Omega ve GLB katsayıları hesaplanmıştır. Güvenirlik bulgularını güçlendirme amacıyla ayrıca örtük özellik analizleri yapılarak (Gültaş, 2014) ölçeğin her bir alt boyutu için iç tutarlıık ve her bir madde için ayırt edicilik değerleri hesaplanmıştır.

AFA analizlerini yapabilmek için öncelikle uygulamadan elde edilen veri setinin faktör analizlerine uygunluğu incelenmiştir. Bu amaçla veri seti için normallik (Rosnow ve Rosenthal, 2008), kayıp değerler, uç değerler, çoklu doğrusallık ve tekillik testleri (Şekercioğlu, 2009), örneklem büyüklüğü testleri (Bryman ve Cramer, 2001; Comrey ve Lee, 1992; Şencan, 2005), Bartlett küresellik testi (Şencan, 2005) ve korelasyon testleri (madde-madde ve anti-image) (Altunışık, Coşkun, Bayraktaroğlu ve Yıldırım, 2005; Günüç ve Kayri, 2010) yapılmıştır. Analizler sonucunda 30 uç değer bulunmuş ve analizlerden çıkarılmış ve geriye kalan verilerle AFA'ya devam edilebileceği yorumu yapılmıştır.

Bu aşamada eldeki veri setine öncelikle Açımlayıcı Faktör Analizi (AFA) yapılmıştır. AFA'da ölçek üç faktörlü yapıyla toplam varyansın \% 45'lik yeterli bir bölümünü açıklamıştır (Büyüköztürk, 2009). Üç faktörlü yapıda faktör yük değerlerinin tüm maddeler için yeterli bulunan 0.4 üzerinde olduğu (Beavers vd., 2013) fakat bazı maddelerde binişik yük değerleri bulunduğu görülmüştür. Buna karşın üç faktörlü modelde ortak faktör varyanslarının bazı maddeler için 0.4 ve bazı maddeler için de 0.3 altında kaldığı görülmüştür. Tutulacak faktör sayısını belirlemek için daha sonra literatürde önerildiği gibi i.) K1- Kaiser'in birden büyük özdeğer (eigenvalue) kuralı, ii.) Cartell'in scree plot (yamaç birikinti grafiği) yöntemi, iii.) Velicer'in MAP(Minimum Average Partial) testi ve iv.) Horn'un paralel analizi birlikte kullanılmıştır (Ledesma ve Valero-Mora, 2007). Bu testlerden ilki tutulacak faktör sayısını altı olarak bulurken diğer üç test üç olarak bulmuştur. Tüm bu bulgularla AFA sonucunda ölçeğin üç faktörlü yapıda olduğu yorumu yapılmıştır.

Daha sonra eldeki veri setine DFA yapılmıştır. DFA'da uyum indeksi değerleri RMSEA = $0.05, \mathrm{NFI}=0.95$ ve $\mathrm{NNFI}=0.96, \mathrm{GFI}=0.90, \mathrm{AGFI}=0.88, \mathrm{CFI}=0.96$ olarak elde edilmiştir. $\mathrm{X} 2$ ve $\mathrm{X} 2$ /sd değerleri sınırda olmakla birlikte diğer tüm uyum değerlerinin kabul edilebilir düzeyde olduğu ve ölçeğin üç faktörlü modele iyi uyum sağladığı görülmüştür (Bryne, 2001). Bundan sonra güvenirlik analizlerine geçilmiştir. Bu kapsamda madde-toplam korelasyonları 0.394 0.801 aralığında yeterli bulunmuştur (Derebaşı, 2004). Epistemolojik İnançlar Ölçeği Türkçe Formu faktörleri için alfa katsayıları çaba alt boyutu için 0.88 , yetenek alt boyutu için 0.88 ve tek bir doğru alt boyutu için 0.85 olarak bulunmuştur. Bu değerlere göre ölçeğin her üç faktörü de kabul edilebilir düzeyde güvenilir bulunmuştur (Tezbaşaran, 1996).

Güvenirlik analizlerini güçlendirmek ve doğrulamak için ayrıca örtük özellik analizleri yapılmıştır. Örtük özellik veya başka bir ifadeyle MTK analizlerinde ölçeğin her bir alt boyutunun güvenilir (RMSEA < 0.05 ) ve maddelerin büyük bir bölümü için ayırt edicilik parametrelerinin yeterli (>1) olduğu gösterilmiştir (Gültaş, 2014; Ledesma ve Valero-Mora, 2007).

Geçerlik ve güvenirlik analizlerinde eldeki veri setinin üç alt boyutlu (faktörlü) modeli ortaya koyduğu ve doğruladığı bulunmuştur. Bununla birlikte modele uymayan veya modelde zayıf kalan maddeler de AFA, DFA ve güvenirlik analizlerinde gösterilmiştir. Yapılan tüm analizler sonucunda 35 maddelik tam ölçeği öğretmeni adayları için üç boyutlu yapıda kullanmak uygun görünmektedir. Ancak zayıf olan maddelerin gözden geçirilmesi veya çıkarılması da önerilebilir. En güvenilir görünen maddeler kullanılarak ölçeğin 29 maddelik veya 23 maddelik kısaltılmış formlarını da kullanmak mümkündür. Eklerde verilen ve zayıf maddelerin çıkarılmasıyla elde edilen 29 veya 23 maddelik Kısaltılmış Epistemolojik İnançlar Ölçeği için AFA'da açıklanan toplam varyansın yükseldiği, madde yük değerlerinin arttığı, 
DFA'da uyum parametrelerinin iyileştiği, madde-toplam korelasyonları ve iç tutarlılık katsayılarının yükseldiği ve örtük değişken analizlerinde her bir maddenin ayırt ediciliğinin birin üzerinde kaldığı bulunmuştur.

$\mathrm{Bu}$ nedenlerle ölçeğin 35 maddelik tam sürümünü kullanarak yapılan önceki çalışmalarla karşılaştırma yapmak gerekirse 35 maddelik tam ölçek kullanılabilir. Ancak amaç, daha kısa ve daha geçerli ve güvenilir bir ölçekle epistemolojik inançları ölçmek olursa 29 veya 23 maddelik kısaltılmış formların kullanılması önerilebilir.

Deryakulu ve Büyüköztürk (2002) tarafından Türkiye bağlamında 626 üniversite öğrencisi üzerinde ilk defa yapılan epistemolojik inançlar ölçeğinin uyarlama çalışmasında yapılan AFA ve DFA sonucunda 3 faktörlü bir yapı bulunmuştur. Bu araştırma kapsamında ise 1242 kişilik daha büyük bir örneklemde ve farklı bölümlerden öğretmen adayları üzerinde geçerlik ve güvenirlik doğrulanmıştır. Güncel ve daha güçlü bu sonucun alana katkı sağlaması umulmaktadır. Bu yeni değerlendirme ile ölçeğin daha güncel ve kısaltılmış formları araştırmacıların kullanımına sunulmuştur.

Üçüncü faktör olan "tek1doğru" ile ikinci faktör olan "yetenek" faktörlerinin arasında yüksek korelasyon $(r=0.76)$ ve mantık bağı bulunması ve bazı maddelerin AFA'da bu iki faktör arasında binişik çıkmasından yola çıkarak yeni çalışmalarda bu ölçeğin faktör yapısının "çaba" ve "yetenek" olarak ikiye düşürülmesiyle daha da net ölçümler yapılabileceği düşünülebilir. Bu çalışmada geçerlik ve güvenirliği ortaya konulan ölçekle büyük ölçekli ve farklı örneklemler üzerinde yeni çalışmalar yapılabilir. Bu çalışmada üç faktörlü yapıda geçerlilik ve güvenirlik kanıtları ortaya konan ölçeğin cinsiyet, yaş, bölüm, öğretim programı ve sınıf değişkenlerine göre yapısal eşitliğinin modellenmesi yararlı olacaktır. Bir başka yararlı çalışmanın da farklı bölümlerden öğretmen adayları için epistemolojik inançlar yönünden örtük sınıf analiziyle anlamlı kümelenmelerin araştırılması olacağı düşünülmektedir. Bu çalışmada geçerlilik ve güvenirlik kanıtları ortaya konulan ölçeği kullanarak yapılacak yeni çalışmalarda öğretmenlerin epistemolojik inançlarının başka değişkenlerle ilişkileri daha sağlam bir şekilde ortaya konulabilir.

\section{KAYNAKLAR}

Altunışık, R., Coşkun, R., Bayraktaroğlu, S., ve Yıldıım, E. (2010). Sosyal bilimlerde araştırma yöntemleri: SPSS uygulamalı. Sakarya yayıncılık.

Arslantaş, H. A. (2016). Epistemological beliefs and academic achievement. Journal of Education and Training Studies, 4(1), 215-220.

Aypay, A. (2011). Epistemolojik inançlar ölçeğinin Türkiye uyarlaması ve öğretmen adaylarının epistemolojik inançlarının incelenmesi. Eskişehir Osmangazi Üniversitesi Sosyal Bilimler Dergisi, 12(1), 1-15.

Aydın, S. (2014) Illköğretim matematik öğretmeni adaylarının öğretme bilgilerinin, inanışlarının ve öğrenme fırsatlarının üniversiteler ve TEDS-M sonuçlarına göre karşılaştırılması. Yayınlanmamış doktora tezi. Karadeniz Teknik Üniversitesi, Eğitim Bilimleri Enstitüsü, Trabzon.

Baxter-Magolda, M. (1992). Knowing and reasoning in college: gender related patterns in students' intellectual development. San Francisco, CA: Jossey-Bass.

Beavers, A. S., Lounsbury, J. W., Richards, J. K., Huck, S. W., Skolits, G. J., \& Esquivel, S. L. (2013). Practical considerations for using exploratory factor analysis in educational research. Practical assessment, research \& evaluation, 18(6), 1-13. 
Biçer, B., Er, H. ve Özel, A. (2013). Öğretmen adaylarının epistemolojik inançları ve eğitimöğretim faaliyetlerine ilişkin benimsedikleri eğitim felsefeleri arasındaki ilişki. Eğitimde Kuram ve Uygulama, 9(3),229-242.

Bryman, A., \& Cramer, D. (2001). Quantitative data analysis with SPSS release 10 for Windows. New York.

Byrne, B. M. (2001). Structural equation modeling with AMOS: Basic concepts, applications, and programming. Mahwah, NJ: Lawrence Erlbaum Associates, Inc.

Brownlee, J., Purdie, N., \& Boluton-Lewis, G. (2001). Changing Epistemological Beliefs in PreService Teacher Education Students. Teaching in Higher Education, 6(2), 247-268.

Buehl, M. M., \& Alexander, P. A. (2005). Motivation and performance differences in students' domain-specific epistemological belief profiles. American Educational Research Journal, $42,697-726$.

Büyüköztürk, Ş. (2007). Sosyal Bilimler için Veri Analizi El Kitabı: İstatistik, Araştırma Deseni, SPSS Uygulamaları ve Yorum. (Yedinci Baskı). Ankara: PEGEM A Yayıncılık.

Cam, A., Sulun, Y., Topcu, M. S. ve Güven, G. (2015). The examination of pre-service teachers' epistemological beliefs in terms of Hofer's and Hammer \& Elby's view, Procedia-Social and Behavioral Scieences, 182,249-253.

Canpolat, M. (2016). The prediction of physical education teacher candidates' achievement goals regarding their learning and studying approaches and epistemological beliefs. International Online Journal of Educational Sciences, 8(2), 83-92.

Chan, K.-W. (2004). Preservice teachers' epistemological beliefs and conceptions about teaching and learning: cultural implications for research in teacher education. Australian Journal of Teacher Education, 29(1), 1-13.

Comrey, A. L. and Lee, H. B. (2013). A first course in factor analysis. Psychology Press.

Conley, A. M., Pintrich, P. R., Vekiri, I., \& Harrison, D. (2004). Changes in epistemological beliefs in elementary science students. Contemporary Educational Psychology, 29, 186-204.

Derebaşı, I. (2004). Evlilik doyumu ölçeğinin (MSI-R) madde cevap kuramına dayalı olarak psikometrik özelliklerinin incelenmesi ve adaptasyon çalışması. Yayınlanmamış Doktora Tezi, Ege Üniversitesi Sosyal Bilimler Enstitüsü, İzmir.

Deyakulu, D. ve Büyüköztürk, Ş. (2002). Epistemolojik inanç ölçeğinin geçerlik ve güvenirlik çalışması. Eğitim Araştırmaları, 8, 111-125.

Deryakulu, D. ve Bıkmaz, F. (2003). Bilimsel epistemolojik inançlar ölçeğinin geçerlik ve güvenirlik çalışması. Eğitim Bilimleri ve Uygulama, 2(4), 243-257.

Deyakulu, D. ve Büyüköztürk, Ş. (2005). Epistemolojik inanç ölçeğinin faktör yapısının yeniden incelenmesi: Cinsiyet ve öğrenim görülen program türüne göre epistemolojik inançların karşılaştırılması. Eğitim Araştırmaları, 18, 57-70.

Dunn, T. J., Baguley, T., \& Brunsden, V. (2014). From alpha to omega: A practical solution to the pervasive problem of internal consistency estimation. 105(3), 399-412.

Erdem, M. (2008), The effect of the blended teaching practice process on prospective teachers' teaching self-efficacy and epistemological beliefs. Eurasian Journal of Educational Research, 30, 81-98. 
Gültaş, M.(2014). Work Discipline Compound Personality Scale Development with Item Response Theory. Unpublished dissertation thesis. Middle East Technical University, Graduate School of Social Sciences, Ankara.

Günüç, S., \& Kayri, M. (2010). Türkiye'de internet bağımlılık profili ve internet bağımlılık ölçeğinin geliştirilmesi: Geçerlik-güvenirlik çalışması. Hacettepe Üniversitesi Eğitim Fakültesi Dergisi, 39(39).

Hashweh, M. Z. (1996). Effects of science teachers' epistemological beliefs in teaching. Journal of Research in Science Teaching, 33(1), 47-63.

Henson, R. K., \& Roberts, J. K. (2006). Use of exploratory factor analysis in published research common errors and some comment on improved practice. Educational and Psychological measurement, 66(3), 393-416.

Hofer, B. K., and Pintrich, P. R. (1997). The development of epistemological theories: Beliefs about knowledge and knowing and their relation to learning. Review of Educational Research, 67(1), 88-140.

Hofer, B. K. (2001). Personal epistemology research: Implications for learning and teaching. Educational Psychology Review, 13, 353-383.

Hofer, B. K. (2002). Personal epistemology as a psychological and educational construct: An introduction. In B. K. Hofer ve P. R. Pintrich (Eds). Personal epistemology: The psychological of beliefs about knowledge and knowing (pp.3-14). Mahwah, NJ: Lawrance Erlbaum.

İçen, M., İlğan, A. ve Göker, H. (2013). Sosyal bilgiler öğretmen adaylarının epistemolojik inançlarının analizi. Anatoloian Journal of Education Leadership and Instruction. 1(2), 211.

Kampa, N., Neumann, I., Heitmann, P. ve Kremer, K. (2016). Epistemological beliefs in science aperson-centered approach to investigate high school students' profiles. Contemporary Educational Psychology, 46, 81-93.

Kazu, I. Y. ve Erten, P. (2015). Öğretmen adaylarının epistemolojik inançlarının incelenmesi. Dicle Üniversitesi Ziya Gökalp Eğitim Fakültesi Dergisi, 25, 57-75.

King, P. M., \& Kitchener, K. S. (1994). Developing reflective judgment. San Francisco, CA: Jossey-Bass.

Kızılgüneş, B., Tekkaya, C., \& Sungur, S. (2009). Modeling the relations among students'epistemological beliefs, motivation, learning approach, and achievement. The Journal of Educational Research, 102, 243-255.

Köksal, M., S. ve Ertekin, P. (2016). An instrument development study for determining prospective science teachers' science-specific epistemological beliefs. Asia-Pacific on Science Learning and Teaching, 17(1), Article 7.

Ledesma, R. D., \& Valero-Mora, P. (2007). Determining the number of factors to retain in EFA: An easy-to-use computer program for carrying out parallel analysis. Practical assessment, research \& evaluation, 12(2), 1-11.

Mason, L., Boscolo, P., Tornatora, M. C., \& Ronconi, L. (2013). Besides knowledge: A crosssectional study on the relations between epistemic beliefs, achievement goals, selfbeliefs, and achievement in science. Instructional Science, 41, 49-79. 
Oksal, A, Şenşekerci, E. ve Bilgin, A. (2006). Merkezi epistemolojik inançlar ölçeğinin geliştirilmesi. Uludağ Üniversitesi Eğitim Fakültesi Dergisi, 19(2), 371-381.

Pamuk, S., Sungur, S. ve Oztekin, C. (2016). A multilevel analysis of students' science achievements in relation to their self-regulation, epistemological beliefs, learning environment perceptions, and teachers' personal characteristics. International Journal of Science and Mathematic Education,

Peters, G. J. Y. (2014). The alpha and the omega of scale reliability and validity: why and how to abandon Cronbach's alpha and the route towards more comprehensive assessment of scale quality. European Health Psychologist, 16(2), 56-69.

R Development Core Team. (2014) . R: A language and environment for Statistical Computing. Vienna, Austria. Retrieved from http://www.r-project.org/

Rosnow, R. L., \& Rosenthal, R. (2008). Assessing the effect size of outcome research, in Nezu, Arthur M. and Nezu, Christine Maguth (Eds), Evidence-based outcome research: A practical guide to conducting randomized controlled trials for psychosocial interventions, (pp. 379-401). New York, NY, US: Oxford University Press, xxv, 486 pp.

Santor, D. A., Haggerty, J. L., Lévesque, J. F., Burge, F., Beaulieu, M. D., Gass, D., \& Pineault, R. (2011). An overview of confirmatory factor analysis and item response analysis applied to instruments to evaluate primary healthcare. Healthcare Policy, 7(Spec Issue), 79.

Saylan, A., Armağan, F. Ö. ve Bektaş, O. (2016). The relationship between pre-service science teachers' epistemological beliefs and preferance for creating a constructivist learning environment. European Journal of Science and Mathematics Education, 4(2), 251-267.

Schommer, M. (1990). Effects of beliefs about the nature of knowledge on comprehension. Journal of educational psychology, 82(3), 498-508.

Schommer, M., Crouse, A., \& Rhodes, N. (1992). Epistemological beliefs and mathematical text comprehension: Believing it is simple does not make it so. Journal of Educational Psychology, 84, 435-443.

Schommer, M. (1994). Synthesizing epistemological belief research: Tentative understandings and provocative confusions. Journal of Educational Psychology, 82, 498-504.

Schommer-Aikins, M. (2002). An evolving theorical framework for an epistemological belief system. In B. K. Hofer ve P. R. Pintrich (Eds). Personal epistemology: The psychological of beliefs about knowledge and knowing (pp.3-14). Mahwah, NJ: Lawrance Erlbaum.

Schommer-Aikins, M., Unruch, S. ve Morphew, J. (2015). Epistemological belief congruency in Mathematics between vocational technology students and their instructors. Journal of Education and Training Studies, 3(4), 137-145.

Songer, N. B., \& Linn, M. C. (1991). How do students' views of science influence knowledge integration? Journal of Research in Science Teaching, 28, 761-784.

Şahin, E., A., Deniz, H. ve Topçu, H. (2016). Predicting Turkish preservice elementary teachers' orientations to teaching science with epsitemological beliefs, learning conceptions, and learning approaches in science. International Journal of Environmental \& Science Education, 11(5), 515-534

Şekercioğlu, G. (2009). Çocuklar için benlik algısı profilinin uyarlanması ve faktör yapısının farklı değişkenlere göre eşitliğinin test edilmesi. Yayınlanmamış Doktora Tezi, Ankara Üniversitesi, Ankara. 
Şencan, H. (2005). Sosyal ve Davranışsal Ölçümlerde Güvenilirlik ve Geçerlilik. (Birinci Baskı). Ankara: Seçkin Yayınları.

Şenler, B. ve İrven, Ö. (2016). Sınıf öğretmeni adaylarının epistemolojik inançları ile sözdebilimsel inançları. Mersin Üniversitesi Eğitim Fakültesi Dergisi, 12(2), 659-671.

Tabachnick B. G. and Fidel, L. S. (2001). Using multivariate statistics (fourth edition). MA: Allyn \& Bacon, Inc.

Tezbaşaran, Ata. "A.(1996)." Likert Tipi Ölçek Geliştirme Kılavuzu. Ankara: Türk Psikoloji Derneği Yayınları.

Tsai, C.-C., Jessie Ho, H. N., Liang, J.-C., \& Lin, H.-M. (2011). Scientific epistemic beliefs, conceptions of learning science and self-efficacy of learning science among high school students. Learning and Instruction, 21, 757-769.

Trautwein, U., \& Ludtke, O. (2007). Epistemological beliefs, school achievement, and college major: A large-scale longitudinal study on the impact of certainty beliefs. Contemporary Educational Psychology, 32, 348-366.

Türkan, A., Aydın, H. ve Üner, S. (2016). Öğretmen adaylarının çokkültürlü eğitime yönelik tutumları ile epistemolojik inançları arasındaki ilişkinin incelenmesi, ilköğretim Online, 15(1), 148-159.

Worthington, R.L., \& Whittaker, T.A. (2006), "Scale development research: a content analysis and recommendations for best practices". The Counseling Psychologist, 34 (6), 806-838. 


\section{SUMMARY}

Beliefs are investigated in educational studies based on the fact that they are powerful predictors of practices. Beliefs about epistemology are important in that they are concerned with what knowledge is and how it is acquired (Hofer, 2002; Schommer-Aikins, 2002). Many researchers investigated epistemological beliefs and demonstrated various but converging latent traits (Kampa, Neumann, Heitmann and Kremer, 2016; Perry, 1981; Schommer, 1994; Schommer-Aikins, Unruh and Morphew, 2015). In Turkey, several researchers concentrated on beliefs about epistemology and found different factor structures (Arslantaş, 2016; Biçer, Er, Özel, 2013; Canpolat, 2016; Cam, Sulun, Topcu and Guven, 2014; Erdamar, Alpan, 2011; Erdem, 2008; İçen, Illğan, Göker, 2013; Kazu, Erten, 2015; Koksal, Ertekin, 2016; Pamuk, Sungur and Oztekin, 2016; Saylan, Armağan and Bektaş, 2016; Şahin, Deniz and Topçu, 2016; Şenler ve İrven, 2016; Türkan, Aydın and Üner, 2016). In these studies, it is evident that investigation of preservice teachers' epistemological beliefs is important and there are conflicting results about the latent structures under the term epistemological beliefs.

In this study the validity and reliability study of epistemological beliefs scale developed by Schommer (1993) and adapted by Deryakulu and Büyüköztürk (2002) on 1242 Class, Turkish, Science and Social Sciences preservice teachers was explained. Schommer (1993), showed the original scale to have four factors whereas Deryakulu and Büyüköztürk (2002; 2005) reported that its Turkish adaptation had only three factors. In order to confirm the result found by Deryakulu ve Büyüköztürk $(2002 ; 2005)$ it was seen necessary to test the validity and reliability of the Turkish adaptation in a larger and versatile sample. This study was carried out with this purpose. The dataset obtained from this application was exposed to exploratory factor analysis and confirmatory factor analysis in order to demonstrate construct validity. For reliability evidence, corrected item-total correlations, Cronbach's alpha, Mc Donald's omega and Greatest Lower Bound (GLB) coefficients were calculated.

In order to show that factor analyses can be applied to the data, some tests were conducted. Fort his aim normality tests (Rosnow ve Rosenthal, 2008 missing values, extreme values, multicollinearity, singularity tests (Şekercioğlu, 2009), sample size tests (Bryman and Cramer, 2001; Comrey and Lee, 1992; Şencan, 2005), Bartlett's test of sphericity (Şencan, 2005) and correlation tests were performed. As a results of the tests, 30 extreme values were excluded from the study and the remaining data was found suitable for factor analyses.

In exploratory faktor analysis, it was found that three factor structure explained $45 \%$ of total variance and Cartell's scree plot, Velicer and Horn tests all confirmed three factor structure. A clean factor three-factor structure with factor loads bigger than 0,4 supported the same result. In confirmatory factor analysis the goodness-of-fit statistics to three factor structure were found good (RMSEA $=0.05, \mathrm{NFI}=0.95, \mathrm{NNFI}=0.96, \mathrm{GFI}=0.90, \mathrm{AGFI}=0.88, \mathrm{CFI}=0.96)$. These values are accepted to demonstrate acceptable to good levels of fit (Bryne, 2001).

In order to examine the internal consistency of the scale item-total correlations, internal consistency coefficients and latent-variable analysis (item response theory) were used. Item total correlations were found between 0.394 and 0.801 . Item total correlations over 0.30 are accepted as reliable (Derebaşı, 2004). The alfa internal consistency coefficients were found as 0.88 for effort, 0.88 for ability and 0.85 for single truth subdimensions which demonstrate a high level of internal consistency (Tezbaşaran, 1996). Latent variable analysis demonstrated that each factor of the scale fits the model (RMSEA $<0,05)$ and the discrimination power of most of the parameters $(>1)$ were sufficient (Gültaş, 2014; Ledesma and Valero-Mora, 2007). As a result of all analyses, the scale was found valid and reliable with three factor structure and some recommendations were made for weak items. The final results showed that the scale can be used in 29 and 23 item abbreviated versions. The scale might be used in future studies to associate the epistemological beliefs of preservice teachers with other demographic variables or performance indicators. 


\section{Ek 1. Epistemolojik İnançlar Ölçeği (35 Madde)}

\begin{tabular}{|c|c|c|}
\hline & No & Madde \\
\hline ç & 1 & Okullarda öğrencilerin ders çalışma becerilerini geliştirmeye yönelik ayrı bir ders verilmesi yararlı olabilir \\
\hline ç & 2 & Çoğu zaman öğretmenlerimin gerçekte ne kadar bilgili olduklarını merak ederim \\
\hline ç & 4 & Bana göre ders çalışmak ders kitabındaki ayrıntıları değil ana düşünceleri öğrenmek demektir \\
\hline ç & 5 & Bilimsel çalışmaların en önemli kısmı özgün (orijinal) düş̧ünmedir \\
\hline ç & 8 & Otoritelerin görüş birliği içinde olmadıkları konular üzerinde düşünmek bence zihni çalıştıııı bir etkinliktir \\
\hline ç & 9 & Herkes nasıl öğreneceğini öğrenmeye gereksinim duyar \\
\hline ç & 10 & Akıllı olmak soruların yanıtlarını bilmek değil yanıtların nasıl bulunabileceğini bilmektir \\
\hline ç & 11 & Eğer biri bir şeyi kısa sürede anlamıyorsa anlamak için çaba sarf etmeyi sürdürmelidir \\
\hline ç & 15 & Bir ders kitabını anlamanın gerçekte en iyi yolu içindeki bilgileri kendinize göre yeniden düzenlemektir \\
\hline ç & 16 & Öğrenme bilginin zihinde yavaş yavaş birikmesiyle gerçekleşir \\
\hline Ç & 17 & Bugün doğru olan yarın yanlış olabilir \\
\hline Y & 1 & İyi bir öğrenci olmak genellikle bilgileri ezberlemeyi gerektirir \\
\hline Y & 2 & Öğretmenlerin anlattıklarını bazen anlamasınız bile onları doğru olarak kabul etmek zorundasınızdır \\
\hline Y & 3 & Bazıları iyi öğrenci olarak doğar ve başarılı olur diğerleri yaşam boyu sınırlı bir yetenekle kalır \\
\hline Y & 4 & Gerçekten zeki olan öğrencilerin okulda başarılı olmak için çok çalışmalarına gerek yoktur \\
\hline Y & 5 & Zor bir problem üzerinde uzun zaman harcayarak çok çalış̧mak ancak zeki öğrencilere bir yarar sağlar \\
\hline y & 6 & Biri zor bir problemi anlamak için çok fazla çaba harcarsa büyük olasılıkla sonuçta kafası karışır \\
\hline T1D & 3 & Çoğu sözcüğün açık (anlaşılabilir) tek bir anlamı vardır \\
\hline T1D & 4 & Doğru (gerçek) değişmezdir \\
\hline T1D & 5 & Yaşamda ne zaman zor bir sorunla karşılaşsam anneme ve babama danışııım \\
\hline T1D & 6 & Bitiminde belirli bir sonuca ulaşmayan sinema filmlerinden hoşlanmam \\
\hline T1D & 7 & Açık- seçik ve kesin bir yanıtının bulunma olasılı̆ıı olmayan problemler üzerine çalışmak zaman kaybıdır \\
\hline T1D & 8 & Dersini titizlikle planlayan bu planına bağlı kalan hocaları takdir ederim \\
\hline T1D & 9 & Fen bilgisi derslerinin en iyi tarafı çoğu problemin tek bir doğru yanıtının olmasıdır \\
\hline
\end{tabular}




\section{Ek 2. Kısaltılmış Epistemolojik İnançlar Ölçeği (29 Madde)}

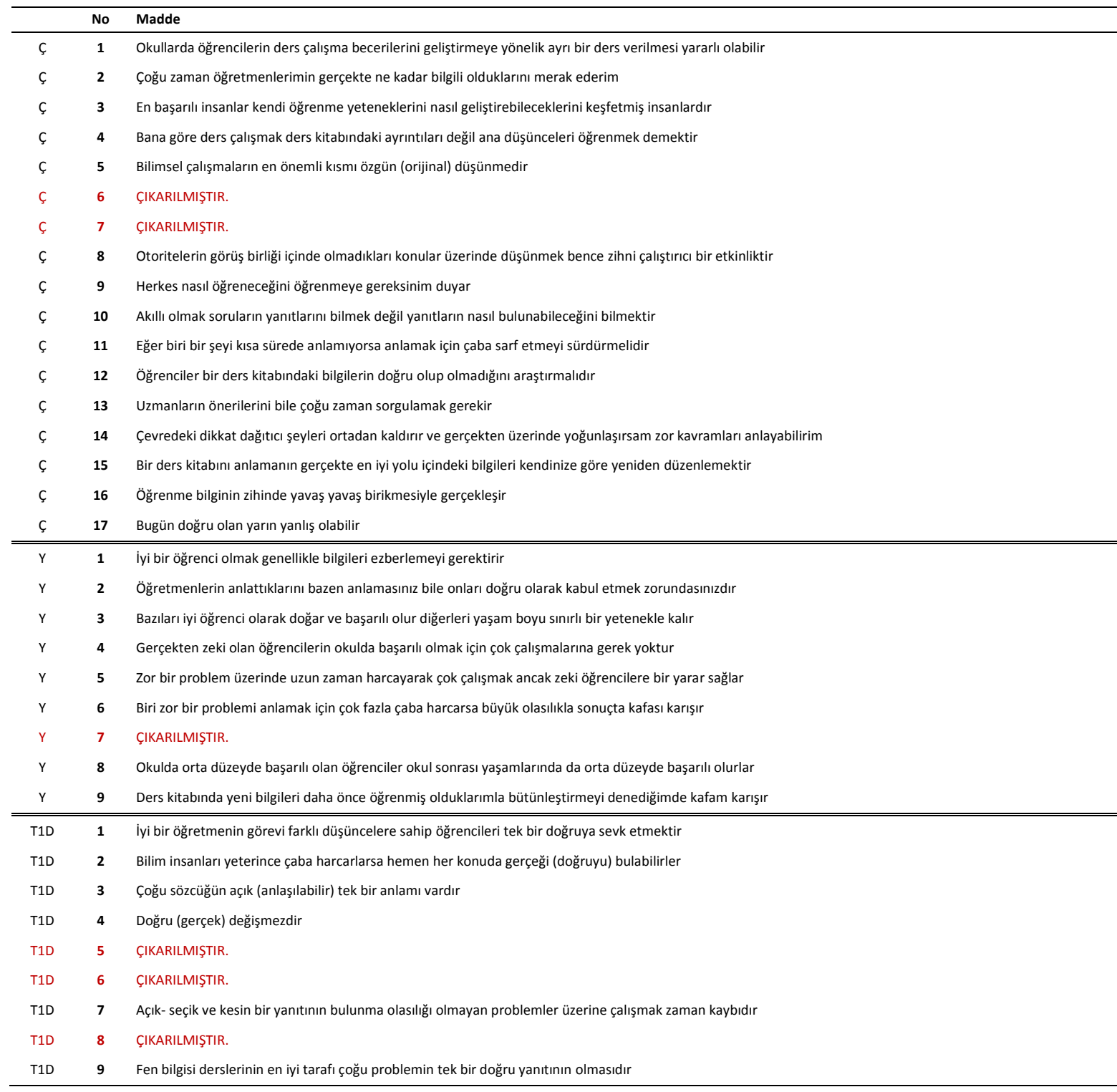




\section{Ek 2. Kısaltılmış Epistemolojik İnançlar Ölçeği (23 Madde)}

\begin{tabular}{|c|c|c|}
\hline & No & Madde \\
\hline ç & 1 & Okullarda öğrencilerin ders çalışma becerilerini geliştirmeye yönelik ayrı bir ders verilmesi yararlı olabilir \\
\hline Ç & 2 & ÇIKARILMIŞTIR. \\
\hline ç & 3 & En başarılı insanlar kendi öğrenme yeteneklerini nasıl geliştirebileceklerini keşfetmiş insanlardır \\
\hline ç & 4 & ÇIKARILMIŞTIR. \\
\hline ç & 5 & Bilimsel çalışmaların en önemli kısmı özgün (orijinal) düşünmedir \\
\hline Ç & 6 & ÇIKARILMIŞTIR. \\
\hline ç & 7 & ÇIKARILMIŞTIR. \\
\hline ç & 8 & ÇIKARILMIŞTIR. \\
\hline ç & 9 & Herkes nasıl öğreneceğini öğrenmeye gereksinim duyar \\
\hline ç & 10 & Akıllı olmak soruların yanıtlarını bilmek değil yanıtların nasıl bulunabileceğini bilmektir \\
\hline ç & 11 & Eğer biri bir şeyi kısa sürede anlamıyorsa anlamak için çaba sarf etmeyi sürdürmelidir \\
\hline Ç & 12 & ÇIKARILMIŞTIR. \\
\hline ç & 13 & Uzmanların önerilerini bile çoğu zaman sorgulamak gerekir \\
\hline ç & 14 & Çevredeki dikkat dağııııı şeyleri ortadan kaldııır ve gerçekten üzerinde yoğunlaşırsam zor kavramları anlayabilirim \\
\hline ç & 15 & Bir ders kitabını anlamanın gerçekte en iyi yolu içindeki bilgileri kendinize göre yeniden düzenlemektir \\
\hline ç & 16 & Öğrenme bilginin zihinde yavaş yavaş birikmesiyle gerçekleşir \\
\hline ç & 17 & ÇIKARILMIŞTIR. \\
\hline Y & 1 & İyi bir öğrenci olmak genellikle bilgileri ezberlemeyi gerektirir \\
\hline Y & 2 & Öğretmenlerin anlattıklarını bazen anlamasınız bile onları doğru olarak kabul etmek zorundasınızdır \\
\hline Y & 3 & Bazıları iyi öğrenci olarak doğar ve başarılı olur diğerleri yaşam boyu sınırı bir yetenekle kalır \\
\hline Y & 4 & Gerçekten zeki olan öğrencilerin okulda başarııı olmak için çok çalışmalarına gerek yoktur \\
\hline Y & 5 & Zor bir problem üzerinde uzun zaman harcayarak çok çalışmak ancak zeki öğrencilere bir yarar sağlar \\
\hline Y & 6 & Biri zor bir problemi anlamak için çok fazla çaba harcarsa büyük olasılıkla sonuçta kafası karışır \\
\hline Y & 7 & ÇIKARILMIŞTIR. \\
\hline $\mathrm{Y}$ & 8 & Okulda orta düzeyde başarılı olan öğrenciler okul sonrası yaşamlarında da orta düzeyde başarılı olurlar \\
\hline Y & 9 & Ders kitabında yeni bilgileri daha önce öğrenmiş olduklarımla bütünleştirmeyi denediğimde kafam karışır \\
\hline T1D & 1 & İyi bir öğretmenin görevi farklı düşüncelere sahip öğrencileri tek bir doğruya sevk etmektir \\
\hline T1D & 2 & ÇIKARILMIŞTIR. \\
\hline T1D & 3 & Çoğu sözcüğün açık (anlaşılabilir) tek bir anlamı vardır \\
\hline T1D & 4 & Doğru (gerçek) değişmezdir \\
\hline T1D & 5 & ÇIKARILMIŞTIR. \\
\hline T1D & 6 & ÇIKARILMIŞTIR. \\
\hline T1D & 7 & Açık- seçik ve kesin bir yanıtının bulunma olasılığı olmayan problemler üzerine çalışmak zaman kaybıdır \\
\hline T1D & 8 & ÇIKARILMIŞTIR. \\
\hline T1D & 9 & Fen bilgisi derslerinin en iyi tarafı çoğu problemin tek bir doğru yanıtının olmasıdır \\
\hline
\end{tabular}

